\title{
THE DEVELOPMENT AND IMPLEMENTATION OF BIOLOGY TEACHING KITS USING SELF REGULATED LEARNING (SRL) STRATEGIES
}

\author{
Erie Agusta ${ }^{1}$ dan Djukri ${ }^{2}$ \\ Science Education Graduate Program State University of Yogyakarta \\ email: bioerie@yahoo.co.id
}

\begin{abstract}
This study was aimed to develop Biology teaching kits using Self Regulated Learning (SRL)-based strategy in senior high schools that have been validated and tested. The study was carried out by using the development strategy of Borg and Gall. The subjects were the tenth grade students of SMA Negeri 1 Sentolo in the academic year of 2014/2015. The data for the validation process and the implementation of the teaching kits were collected through questionnaires and observations. The data of the validator assessment were analyzed using the categorization formula and Borich formula. The data on the try-out were analyzed using the paired sample test. The findings were in the form of teaching kits product for Bryophyta materials for the tenth grade students. The teaching kits had been validated theoretically by experts and teachers, the lesson plans had been validated and simulated, and the teaching kits and research instruments had been tried out in a small scale and implemented in the field.
\end{abstract}

Keywords: teaching kits, Self Regulated Learning (SRL) strategies

\section{PENGEMBANGAN DAN IMPLEMENTASI PERANGKAT PEMBELAJARAN BIOLOGI DENGAN STRATEGI SELF REGULATED LEARNING (SRL)}

\begin{abstract}
Abstrak: Tujuan penelitian pengembangan ini adalah dihasilkannya perangkat pembelajaran biologi berbasis Self Regulated Learningdi SMA yang telah tervalidasi dan teruji. Metode penelitian menggunakan strategi pengembangan Borg dan Gall. Subjek penelitian perangkat pembelajaran adalah siswa kelas X SMAN 1 Sentolo. Teknik pengumpulan data dalam proses validasi dan implementasi perangkat pembelajaran menggunakan angket dan observasi. Data penilaian validator dianalisis dengan rumus kategorisasi, sedang persamaan validator terhadap lembar validasi menggunakan rumus Borich. Data hasil uji coba dianalisis dengan paired sample test. Hasil penelitian berupa produk perangkat pembelajaran pada materi tumbuhan lumut di kelas X SMA. Perangkat pembelajaran tersebut telah divalidasi secara teoretis yang dilakukan oleh ahli dan guru, rencana pelaksanaan pembelajaran tertentu telah diuji secara terbatas keterbacaan dan disimulasikan, perangkat pembelajaran dan instrumen penelitian telah diuji coba terbatas dan lebih luas.
\end{abstract}

Kata kunci: perangkat pembelajaran, strategi self regulated learning

\section{INTRODUCTION}

The changes of elementary and secondary education curriculum in Indonesia have happened since 1945. According to the historical facts, in general, the curriculum changes are divided into three important events, namely 1) the curriculum change in the New Order Era, 2) the curriculum change after the New Order
Era, and 3) the curriculum change in the current democratic development era.

The curriculum change known in the New Order Era includes the 1975 curriculum, the 1984 Student Active Learning or Cara Belajar Siswa Aktif(CBSA), and the 1994 curriculum. The curriculum change at this time happened as the result of the Science and Technology advancement in the West, exactly when 
USA was able to fly Apollo 11 to the moon in 1969. Afterwards, the curriculum change known after the New Order Era includes the 2004 Competency-Based Curriculum or Kurikulum Berbasis Kompetensi (KBK), and the 2006 School-Based Curriculum or Kurikulum Tingkat Satuan Pendidikan (KTSP). The changes at this time were triggered by the change of the centralization system into the decentralization system due to the fall of Suharto regime in 1998.

Meanwhile, the last curriculum change is known as the 2013 Curriculum. This 2013 curriculum change is a refinement of the previous curriculum aimed to improve the quality of the learning process in achieving 21st century grand qualities. It is in line with a statement by Anandiouet al., (2009:8), about "skill and competencies young people will be required to have in order to be effective workers and citizen in the knowledge society of the 21st century".

Along with the demand, then the change in the 2013 Curriculum is done in four National Education Standards (NES) or Standar Nasional Pendidikan (SNP). The four National Education Standards include the graduate standard competences, the core standards, the process standards, and the assessment standards. The changes in these four aspects demand a learning instrument renewal emphasizing on students' activities through scientific approach.

The renewal of this learning instruments happened to all lessons, including Biology subject which is basically familiar with the scientific approach. It is because the Biology learning process actually prioritizes the discovery process through experiments and observation activities. Hence, it can be concluded that in the Biology learning process, the students are demanded to construct their own knowledge.

However, according to the sentinels of Education Office in the 2013 Curriculum implementation assistance report in Sleman Regency High Schools (2013), many teachers had problems in designing core activities where $5 \mathrm{M}$ activities have to be included and implemented in the learning process (Djukri \& Paidi, 2013: 2). Moreover, there were $60 \%$ to $85 \%$ teachers who had no idea about the connection between Core Competences (KI) and Basic Competences (KD), and Graduate Standard Competence (GSC) in the 2013 Curriculum. There is a misunderstanding because currently the competence standard and the basic competence were integrated from GSC. It was different from the previous curriculum in which the GSC was integrated from Competence Standards and Basic Competences. This is considered as the indicator of ineffective teaching.

The report also explained that the competencies that should be achieved by the students according to the core competence $(\mathrm{CC})$ and the basic competence (BC) became more complex, so that the teachers had difficulties in developing the goals and indicators that would be included in the lesson plan. The complexity of $\mathrm{CC}$ and $\mathrm{BC}$ also affected the difficulties in developing assessment instruments and doing authentic assessment. These problems emerge becaause there are many aspects to be assessed by teachers, including students' cognitive, affective, and psychomotor aspectss in the learning process. It is not an easy job, because teachers are demanded to develop assessment instruments which can measure all of the aspects based on the material that is learned by students.

Furthermore, according to an interview conducted in SMA Negeri 1 Sentol, some of biology teachers there still had difficulties in implementing the lesson plan using the scientific approach although the core activity, the lesson plan, the learning steps had been already suitable with the scientific approach. Further problems emerge because of the demand that the teaching periods should not be separated. This may cause boredom when teachers cannot teach and there is no class. SMA Negeri 1 Sentolo was one of the 29 schools in Yogyakarta used as the pilot project for the implementation of the 2013 Curriculum.

From the students' view, the interview results most students still had difficulties in understanding what was taught using the scientific approach. This is because prevviously, the teaching learning process was conducted using 
the teacher-centred approach, not studentcentred. Even most of them thought the absence of their teacher was something worth. This fact actually does not correlate with the education purpose. That is why it is necessary to develop a constructive learning strategy which can improve students' autonomy and intrinsic motivation. The autonomy is defined in the form of students as the main subjects in the learning process. Autonomy is correlated to the metacognitive skill, because the metacognitive skill refers to high order thinking, including active control towards the cognitive process in learning (Ardila, Corbima, dan Zubaidah, 2013:1). Hence, the more autonomy a student has, the higher the metacognitive skill he has. This will also affect their learning achieveent (Ardila, Corbima, dan Zubaidah, 2013:1).

The metacognitive skill is introduced by Flavellin 1976 and is defined as a skill to think, understand and control the learning process. Based on Flavell's perspective, the metacognitive skill is divided into two important parts, namely the metacognitive knowledge and the monitoring \& self regulation (Zohar, 2012:199).

The human metacognitive skill has developed at the age of 3-5 years in the form of planning and self correction hen playing. It continues to develop until 6-8 years old and developed rapidly upon entering the middle school age (Veenman, 2012:21). In this research, metacognitive measurement is based on a concept developed by Schraw \& Dennison, (1994). Schraw \& Dennison (1994:460) divided the metacognitive skill into two major components, namely knowledge about cognition and regulation of cognition. The knowledge of cognition consists of 3 sub-processes, namely (1) declarative knowledge; (2) procedural knowledge; and (3) conditional knowledge. Declarative knowledge is knowledge about oneself and about strategies that is used. Procedural knowledge is knowledge about how to use strategies, and conditional knowledge is knowledge about when and why to use the strategies. Meanwhile, the regulation of cognition is knowledge concentrated on students' performance to solve a problem (Schraw \& Dennison, 1994:460). This regulation of cognition includes planning, information management strategies, comprehension monitoring, debuging strategies, and evaluation. Based on this concept, Schraw\& Dennison made a standard measurement of metacognitive or MAI (Metacognitive Awarness Inventory). The instrument later on is adapted by Paidi (2008) for high school students in Indonesia.

Ardila, Corbima, and Zubaidah (2013:1) and Imel (2002:3) stated that activities including planning in finishing a task, monitoring, understanding and evaluating cognitive development were metacognitive skills happening in daily life. The activities can be facilitated with the implementation of SRL strategy. The learning process strategy is chosen based on the characteristics of SRL strategy which can direct students to do planning, following development, and monitoring the learning process so that they are actively involved in creating autonomy in their own learning. The occurrence of autonomy through the SRL strategy affects the improvement of the metacognitive skills and learning motivation (Suryanto, 2010:508).

The concept of Self Regulated Learning (SRL) strategy in this study is developed from Santyasa (2013:17) synthesized through the scientific approach. The learning steps can be seen in Table 1.

Meanwhile, there are many learning strategies recommended by The Ministry of Education and Culture for implementing the scientific approach. This study is aimed to give new alternative in learning strategy options, such as Problem Based Learning (PBL) strategy, Project Based Learning (PjBL) strategy, Inquiry, Discovery and Group Investigation (GI) strategy which are widely used. This aim is built upon a study of some research references mentioning students' characteristics from SRL strategy and is very related to the demands of students' competence in 21 st century, the vision of 2013 Curriculum (Wolters, 2010:7). 
Table 1. Synthesized SRL Learning Steps through Scientific Approach

\begin{tabular}{|c|c|c|}
\hline $\begin{array}{l}\text { Self Regulated } \\
\text { Learning (SRL) }\end{array}$ & $\begin{array}{l}\text { Scientific } \\
\text { Approach }\end{array}$ & Synthesis \\
\hline Analyze & Observing & Analyzing Topic \\
\hline Plan & Asking & Observing \\
\hline Implement & $\begin{array}{l}\text { Obtaining } \\
\text { Information }\end{array}$ & Asking \\
\hline $\begin{array}{l}\text { Comprehend/Self- } \\
\text { Reflection }\end{array}$ & Associating & Planning \\
\hline Problem Solve & & $\begin{array}{l}\text { Obtaining } \\
\text { Information } \\
\text { (Implement) }\end{array}$ \\
\hline Evaluate & Communicating & $\begin{array}{l}\text { Associating } \\
\text { (Comprehend \& } \\
\text { Problem Solve) } \\
\text { Communicating }\end{array}$ \\
\hline Modification & & $\begin{array}{l}\text { Evaluating } \\
\text { Modifying }\end{array}$ \\
\hline
\end{tabular}

Furthermore, in this study, the measurement of intrinsic motivation is based on Deci \& Ryan's Intrinsic Motivation Inventory (IMI) standards. According to the study, there are 7 indicators in measuring intrinsic motivation, namely interest, perceived competence, effort/importance, pressure, perceived choice, value, and relatedness. However, it is limited to the aspects of student's interest, competence of understanding, pressure, and choice. Moreover, this standard has also been developed by Paidi (2008) for high school student's psychological state in Indonesia.

In this study material is Bryophyta material. It is because the material characteristic which is easy to find in daily life. So that student's exploration in doing self assignment, encouraging metacognitive skills and learning motivation aspects through SRL strategy, can be more optimally.

Based on the problems stated above, it is necessary to develop a learning instrument appropriate for scientific approach with the implementation of student-centered learning strategy. Therefor, the study done is a development of biology learning instrument with the implementation of SRL strategy to improve student's metacognitive skill and intrinsic motivation of Bryophyta lesson in SMA Negeri 1 Sentolo.
This research development has been done and produced (1) syllabi; (2) lesson plans: (3) worksheets; and (4) assessment instrument. In the next section, there will be explanation of research method, result $\&$ discussion, and conclusion that had been got in this study.

\section{METHOD}

This research development used Borg and Gall (1983:775) development model. The time setting was January 2015. The place setting was SMA Negeri 1 Sentolo Kulon Progo. The population in this study was the tenth grade students of SMA Negeri 1 Sentolo. The total samples were three classes, which were X MIA 1, X MIA 2, and X MIA 3. The sample collection technique was random technique. The research procedure included: (1) introductory study; (2) planning; (3) early product development; (4) product validation and first revision; (5) preliminary field testing; (6) second revision; (7) main field testing; (8) final product revision; and (9) dissemination.

The type of the data in this study included assessment data validator and the result data of implementation/field testing. The assessment data validator for learning instrument used validation sheet instrument. As for the implementation used (1) observation sheet of learning instrument implementation; (2) Metacognitive Awarness Inventory (MAI) sheet to measure metacognitive skills, adopted from Paidi (2008); and (3) Intrinsic Motivation Inventory (IMI) sheet to measure learning motivation, adopted from Paidi (2008). Data collection technique in validation process and instruments implementation was using questionnaire technique. Whereas for data collection of learning instrument implementation was using observation technique. Data analysis technique of the assessment validator was using Mardapi's (2008:123) categorization formula. Then, for validator equation analysis of the validation sheet was using Borich's formula (1994:385). While for implementation data of learning instrument improving metacognitive skill and student's learning motivation was using t-test 
analysis technique type paired samples t-test with the help of SPSS Ver. 16.

\section{RESULTS AND DISCUSSIONS}

\section{The Development Results}

After arranging the draft, so it will be continued to the validity process. The validity process in this research involved two experts and three pilot project high school teachers. The validity result can be seen in the Table 2 and Table 4.

It was obtained that the result of categorized learning instruments validity was "very good". Moreover, to support validation sheet quality, so it will be continued with the analysis result of perception of two experts to the validator sheets in Table 4.

Table 2. Recapitulation of Data Validation Results of Learning Instruments Draft from Experts and the 2013 Curriculum Pilot Project High School Biology Teachers

\begin{tabular}{|c|c|c|c|c|c|c|}
\hline \multirow[t]{2}{*}{ No } & \multirow[t]{2}{*}{ Learning Instrument } & I & II & III & IV & $\mathrm{V}$ \\
\hline & & & & \multicolumn{3}{|c|}{$\begin{array}{c}\text { Pilot Project High School } \\
\text { Biology Teachers }\end{array}$} \\
\hline \multirow{2}{*}{1} & Syllabi & 33 & 35 & 34 & 32 & 39 \\
\hline & Category & $\mathbf{A}$ & $\mathbf{A}$ & $\mathbf{A}$ & $\mathbf{A}$ & $\mathbf{A}$ \\
\hline \multirow{2}{*}{2} & Lesson Plans & 53 & 56 & 53 & 52 & 58 \\
\hline & Category & $\mathbf{A}$ & $\mathbf{A}$ & $\mathbf{A}$ & $\mathbf{A}$ & $\mathbf{A}$ \\
\hline \multirow{2}{*}{3} & Worksheets & 107 & 105 & 116 & 96 & 117 \\
\hline & Category & $\mathbf{A}$ & $\mathbf{A}$ & $\mathbf{A}$ & $\mathbf{A}$ & $\mathbf{A}$ \\
\hline \multirow{2}{*}{4} & Assessment Instruments & 93 & 97 & 96 & 87 & 104 \\
\hline & Category & $\mathbf{A}$ & $\mathbf{A}$ & $\mathbf{A}$ & $\mathbf{A}$ & $\mathbf{A}$ \\
\hline
\end{tabular}

Table 3. Categorization of Learning Instrument Assessment Score

\begin{tabular}{cccc}
\hline Learning Instrument & Interval & Score & Category \\
\hline \multirow{3}{*}{ Syllabi } & $\mathrm{X} \geq 30-40$ & $\mathrm{~A}$ & Very good \\
& $30>\mathrm{X} \geq 25$ & $\mathrm{~B}$ & Good \\
& $25>\mathrm{X} \geq 20$ & $\mathrm{C}$ & Adequate \\
& $\mathrm{X}<20$ & $\mathrm{D}$ & Poor \\
& $\mathrm{X} \geq 48-64$ & $\mathrm{~A}$ & Very good \\
& $48>\mathrm{X} \geq 40$ & $\mathrm{~B}$ & Good \\
Lesson Plans & $40>\mathrm{X} \geq 32$ & $\mathrm{C}$ & Adequate \\
& $\mathrm{X}<32$ & $\mathrm{D}$ & Poor \\
& $\mathrm{X} \geq 96-128$ & $\mathrm{~A}$ & Very good \\
& $96>\mathrm{X} \geq 80$ & $\mathrm{~B}$ & Good \\
& $80>\mathrm{X} \geq 64$ & $\mathrm{C}$ & Adequate \\
Worksheets & $\mathrm{X}<64$ & $\mathrm{D}$ & Poor \\
& $\mathrm{X} \geq 81-108$ & $\mathrm{~A}$ & Very good \\
& $81>\mathrm{X} \geq 67,5$ & $\mathrm{~B}$ & Good \\
& $67,5>\mathrm{X} \geq 54$ & $\mathrm{C}$ & Adequate \\
Assessment Instruments & $\mathrm{X}<54$ & $\mathrm{D}$ & Poor \\
& & & \\
\hline
\end{tabular}


Table 4. The Analysis Result of Two Experts Perception

\begin{tabular}{lc}
\hline \multicolumn{1}{c}{ Learning Instruments } & $\%$ \\
\hline Syllabi & 100 \\
Lesson plans & 97,2 \\
Worksheets & 99 \\
Assessment Instruments & 97,9 \\
\hline
\end{tabular}

It could be concluded that the equation perception of two experts validator toward sheets showed same perception. It could be seen from the percentage score, exceeding $75 \%$. It became representation that validation sheets had better qualities in obtaining validation data recapitulation of learning instruments. After going through the experts and teachers validation process, it was continued with the readability of worksheets, MAI instruments and IMI by 15 students. The result was presented in Table 5 and Table 6.

Table 5. Data Result Recapitulation of MAI and IMI Readability by Students

\begin{tabular}{cccc}
\hline No & Students & Total & Category \\
\hline 2. & Student 2 & 26 & A \\
3. & Student 3 & 26 & A \\
4. & Student 4 & 28 & A \\
5. & Student 5 & 27 & A \\
6. & Student 6 & 25 & A \\
7. & Student 7 & 30 & A \\
8. & Student 8 & 28 & A \\
9. & Student 9 & 32 & A \\
10. & Student 10 & 26 & A \\
11. & Student 11 & 25 & A \\
12. & Student 12 & 24 & A \\
13. & Student 13 & 22 & B \\
14. & Student 14 & 24 & A \\
15. & Student 15 & 25 & A \\
\hline
\end{tabular}

Table 6. Categorization of MAI and IMI Instruments Readability

\begin{tabular}{ccc}
\hline Interval & Score & Category \\
\hline $\mathrm{X} \geq 24-32$ & A & Very good \\
$24>X \geq 20$ & B & Good \\
$20>X \geq 16$ & C & Adequate \\
$X<16$ & D & Poor \\
\hline
\end{tabular}

It could be concluded that MAI and IMI instruments were appropriate to be read. It was shown in the readability recapitulation results achieving "very good and good" category.

Table 7. Data Recapitulation Result of Worksheets Readability by Students

\begin{tabular}{cccc}
\hline No & Name & Total & Category \\
\hline 1. & Student 1 & 86 & A \\
2. & Student 2 & 71 & B \\
3. & Student 3 & 84 & A \\
4. & Student 4 & 71 & B \\
5. & Student 5 & 89 & A \\
6. & Student 6 & 68 & B \\
7. & Student 7 & 66 & B \\
8. & Student 8 & 85 & A \\
9. & Student 9 & 80 & A \\
10. & Student 10 & 74 & B \\
11. & Student 11 & 81 & A \\
12. & Student 12 & 77 & B \\
13. & Student 13 & 67 & B \\
14. & Student 14 & 60 & C \\
15. & Student 15 & 79 & A \\
\hline
\end{tabular}

Table 8. Worksheets Readability Score Categorization

\begin{tabular}{ccc}
\hline Interval & Score & Category \\
\hline $\mathrm{X} \geq 78-104$ & $\mathrm{~A}$ & Very good \\
$78>\mathrm{X} \geq 65$ & $\mathrm{~B}$ & Good \\
$65>\mathrm{X} \geq 52$ & $\mathrm{C}$ & Adequate \\
$\mathrm{X}<52$ & $\mathrm{D}$ & Poor \\
\hline
\end{tabular}

It could be concluded that the worksheets was appropriate to be read. It was shown in the readability recapitulation result that most of it was categorized as "very good and good". After going through developmental phase, then it was continued with learning instruments implementation/testing. The results consisted of two tests, namely preliminary field test and main field test. 


\section{Preliminary Field Test Result}

Preliminary field test involved tenth grade MIA 1 or X MIA 1 and used draft IV as the revision from validator assessment result and students' readability result. The preliminary field test is shown in Table 9.

Table 9. Paired Samples T-Test Result

\begin{tabular}{ccc}
\hline Aspects & $\begin{array}{c}\text { Paired Samples } \\
\text { t Test } \\
\text { Significance } \\
\text { Score }\end{array}$ & Decision \\
\hline Metacognitive & $0,94>0,05$ & $\begin{array}{c}\text { No } \\
\text { improvement }\end{array}$ \\
\hline Learning & $0,00<0,05$ & Improved \\
Motivation & & \\
\hline
\end{tabular}

It could be concluded that in the prelimnary field test class there was a significant improvement in learning motivation, with the significant score of 0,00 . This was less than the value of confidence level by $5 \%$. As for metacognitive significance score was 0,94 . This was bigger than the value of confidence level by $5 \%$, making it could be concluded that there was no improvement.

\section{Main Field Test Result}

After going through preliminary field test, it was then continued with main field test. This test was using control class and experimental class. The control class involved X MIA 3, and the experimental class involved X MIA 2 . Additionally, the implementation of experiment class was based on the revision result of preli- minary field test implementation. The main field test design was shown in Table 10 below.

\section{Table 10. Main Field Test Design}

\begin{tabular}{cccc}
\hline Class & Pre Test & Treatment & Post Test \\
\hline Experiment & $\mathrm{O}$ & $\mathrm{O}$ & $\mathrm{O}$ \\
\hline Control & $\mathrm{O}$ & $\mathrm{X}$ & $\mathrm{O}$ \\
\hline
\end{tabular}

Before doing t-test analysis, it would be continued with hypothesis requirement tests. The hypothesis requirement tests in this research were data normality test and homogeneity of variant test which was shown in Table 11.

It could be concluded that metacognitive data and learning motivation data obtained at the main field test was normal distributed. It could be seen in the significance score more than $5 \%(0,05)$. Next, after going through requirement data normality test, it was continued with homogeneity of variant test. The test for metacognitive variant homogeneity and learning motivation before and after treatment, both in class control and experiment control, it was shown in Table 12.

It could be concluded that metacognitive variant and learning motivation were homogeny. It could be seen from data significance score which reached more than 5\% $(0,05)$.

After going through requirement test stage, the next was proper data to be followed up with hypothesis test through t-test. The result was shown in Table 13.

Table 11. Result of Main Field Test Data Normality

\begin{tabular}{llcc}
\hline \multirow{2}{*}{ Aspects } & \multicolumn{2}{c}{ Data } & \multicolumn{2}{c}{ Significance } \\
\cline { 3 - 4 } & Pre Experiment & Kolmogorov-Smirnov $^{\mathrm{a}}$ & Shapiro-Wilk $^{*}$ \\
\multirow{3}{*}{ Metacognitive } & Pre Conrol & 0,122 & 0,354 \\
& Post Experiment & 0,157 & 0,409 \\
& Post Control & 0,200 & 0,130 \\
& Pre Experiment & 0,125 & 0,312 \\
\multirow{3}{*}{ Learning Motivation } & Pre Conrol & 0,200 & 0,826 \\
& Post Experiment & 0,200 & 0,061 \\
& Post Control & 0,200 & 0,651 \\
& & 0,200 & 0,237 \\
\hline
\end{tabular}


Table 12. The Result of Variant Homogeneity Main Field Test

\begin{tabular}{lcc}
\hline \multicolumn{1}{c}{ Aspects } & Data & Significance \\
& (Experiment \& Control) & Levene Statistic \\
\hline \multirow{2}{*}{ Metacognitive } & Before Treatment & 0,329 \\
& After Treatment & 0,661 \\
\multirow{2}{*}{ Learning Motivation } & Before Treatment & 0,629 \\
& After Treatment & 0,788 \\
\hline
\end{tabular}

Tabel 13. Paired Samples T-Test Result

\begin{tabular}{cccc}
\hline Class & Aspects & $\begin{array}{c}\text { Significance Score of } \\
\text { Paired samples t test }\end{array}$ & Decision \\
\hline \multirow{2}{*}{ Experiment } & Metacognitive & $0,001<0,05$ & Improved \\
& Learning Motivation & $0,002<0,05$ & Improved \\
\multirow{2}{*}{ Control } & Metacognitive & $0,922>0,05$ & No improvement \\
& Learning Motivation & $0,636>0,05$ & No improvement \\
\hline
\end{tabular}

It could be concluded that the class using SRL strategy learning instrument gave better effectiveness in increasing student's metacognitive skill and learning motivation. Meanwhile, the class using conventional learning instrument did not show such effectiveness.

\section{Discussion}

\section{Discussion of Preliminary Field Test}

Based on the result of preliminary test analysis on Table 9, it represented that the learning instruments gave quite an impact to the analysis result. It could be seen from some of activities which was not optimum.

In the first meeting of preliminary test, it reached only about $95,8 \%$ in the implementation process, because un-optimum time management of teaching process. In this meeting, the most consuming time activity was managing students when observing Bryophyta around school area. At that time, many groups gathered in one location, so that the observation was not optimum and they only found one kind of Bryophyta, which was moss leaves.

In this meeting, students' enthusiasm was shown. It could be seen by how they were interested in gathering together with their peers to know directly the characteristics of Bryophyta. Even in formulating the question stage, students can formulate in depth questions about metagenesis and reproduction of Bryophyta. However, students organization was not effective enough, making this activity a constraint for the next learning activities. Even, the use of herbarium media Marchantiapolymorpha also brought students' enthusiasm to see parts of the Bryophyta. It was shown in their discussion and questionsection reaction in the learning process between students in their groups with the teacher.

In the second meeting of preliminary test, the implementations had already reached $100 \%$. However, even though generally had been good enough, there were some implementations which became constraints. For example, the paper format submitted because most students forgot the criteria; causing presentation time, which came afterwards, not quite effective and consuming time allocated for question section. The reflection activity was then ineffective since the time became limited.

\section{Main Field Test Discussion}

The improvement of metacognitive skill and learning motivation shown in the experimental class became a representation that learning implementation happened optimally. It was because the implementation process had been revised based on preliminary field test implementation. For example, in the second meeting, sufficient time allocation gave opportunities for the teachers to improve students' metacognitive skill. In the second meeting, when association 
stepsynthesized with comprehend and problem solve occured, teacher could give time for students to recheck, to ask the poorly understood material in doing task, and to discuss the lesson with their peers. Then, the implementation of communication step also occurred effectively, making self reflection activity in the worksheet flew smoothly.

Moreover, in observing Bryophyta activity around school area, students had spread and were well coordinated. It made them found two kinds of Bryophyta, instead of one as in the preliminary test, moss leaves and liverworts. This activity, not only students were well coordinated, but also gave impact of intrinsic motivation that pushed students to know directly Bryophyta using magnifying glass. Despite the tools used were simple, this activity still could push students' enthusiasm in formulating question and gathering information.

Meanwhile, as explained before in the preliminary test, herbarium Marchantiapolymorpha also added students' enthusiasm in observing parts of Bryophyta, such as arkegonium and anteredium Marchantiapolymorpha

Whilst there were no metacognitive skill and learning motivation improvement in the control class represented the learning stepsused had not yet been able to direct students' metacognitive skill and learning motivation. The learning stepsof control class only focused on activities in which concept mastery was suggested. For example, in the worksheet activity of the first meeting, students were only directed to answer questions through observing provided metagenesis cycle. Not in a way where students could directly ask what metagenesis is and how the process is.

Additionally, if seen at the worksheet activity where students were asked to observe parts of Bryophyta, they were only directed to observe Bryophyta brought by their own teacher, not the ones they found themselves. It made students' activities limited to indoor activities. This could not give significant motivation and enthusiasm impact.

In formulating question activity, not all questions were formulated by students. Some of them were provided by the teacher. This then limited students' enthusiasm in following the lesson. So that, the learning process tend to be more text book to answer the provided questions. It did not explore much of students' ability to find the answers from different sources and to discuss it with their classmates.

\section{Discussion on Self Regulated Learning (SRL) Strategy Steps of Learning in Affecting Meta- cognitive Skills and Intrinsic Motivation}

Based on the preliminary and main field test result, it represented that learning instruments through SRL strategy gave student-centered learning pattern which could help students to actively learning in building knowledge, planning, monitoring, self motivating and controlling their learning. Self reflectionstepwas the most important part and became one of the excellences of SRL strategy (Philips, 2006 via Santyasa, 2013:10). This part supported scientific approach and directed students to focus in the learning process, resulting in the acknowledgement of their own weaknesses and strengths (Santyasa, 2013:10). For example, in the association step, in scientific approach, synthesized steps of this learning and SRL steps learning made students not only gather information but also recheck their comprehension on the gathered information, as well as look for problem solving about the information they had not yet comprehended. "The awareness of oneself lacks is a ground to improve, this process gives direct responsibility to the students in getting through the process and achieving optimal learning products," (Santyasa, 2013:10).

Self reflection activity became a representation of students' comprehension about one self and was the most important part of metacognitive skills. According to Anderson \& Krathwohl (2001:59), comprehension about oneself includes comprehension about one's weakness and strength related to cognition and learning. This comprehension will be advantageous for students in getting themselves ready for facing learning process. This statement is also supported by Grotzer and Mittlefehldt (2012:94) who state that reflection activity could help students 
to evaluate their idea structure and adopt it into something clearer and more complex. Self reflection activity will push their logics to judge their understanding and create one in depth understanding concept (Grotzer \& Mittlefehldt, 2012:95). In line with Grotzer \& Mittlefehldt (2012), Hidayat (2012:507) also states that students' understanding/comprehension about learning effort they have is an important factor for the next learning motivation improvement.

Besides knowing their own cognition, when students do self reflection, they also have confidence about their motivations (Anderson \& Krathwohl, 2001:59). Motivation in knowledge taxonomy is divided into three (Anderson \& Krathwohl, 2001:59). First, self efficacy, which was student's belief that he was able to do a certain task. Second, belief of purpose a student has to do a certain task. Third, interest, which was student's perception about his personal interest of one certain task and his decision about how often and what the advantage of the task. So, indirectly, when students self reflected to their learning process, their intrinsic motivation would get involved and became a measurement of their motivation. It also showed how far effectiveness of SRL strategy represents students' motivation and self reflection in learning process.

Another metacognitive aspect involved in this scientific approach-based SRL learning process is knowledge of strategy. The knowledge of strategy includes knowledge about various strategies a student can use in a learning process which can help his cognition aspect (Whitebread \& Cardenas, 2012:104). This aspect was expected to help student in understanding the problem he was facing. That is why, in this development of learning steps of scientific approach, before information gathering, is proceeded with planning step. This activity guides 16 student in answering formulation of the problem they are having. In this planning activity, it would contain strategies students could use. Such as direction to make conceptual map and conducting a paper. Making a conceptual map would help them summarizing material that would be taught and help them in memorizing.
Conducting a paper with group discussion gave them representations of another strategy to obtain information by working together in understanding the material being taught in class. Despite this activity gave strategy representations that would be used by students in answering the formulated questions, it did not limit if they wanted to use another strategy.

Besides, when students tried various strategies, indirectly they would involve procedural and conditional knowledge they have. Procedural knowledge is a knowledge about the well and appropriate use of strategies (Anderson \& Krathwohl, 2001:57). Conditional knowledge is a knowledge to choose which knowledge is easier to use in understanding material (Anderson \& Krathwohl, 2001:57). Both aspects are involved in the implementation of scientific approach learning through SRL strategy.

The addition of planning activity before information gathering was also based on interview result and observation that the researcher obtained. In the third learning step through scientific approach, students were able to do information gathering directly to answer the formulated questions they were having. Whereas most students were still confused with the 2013 Curriculum learning. This became a representation that students' psychology was still in transition from teacher-centered learning process into student-centered learning process. That is why, the synthesis of planning activity was considered as an effective way to guide students in gathering information. So that achievement in answering the formulated questions was within reach.

Aside from above explanations, this discussion was also supported by some studies. According to Asmari \& Ismail (2012:178), the use of SRL can push individuals to increase their motivation and active participation in directing metacognitive process when they were learning.

Moreover, in line with Asmari \& Ismail (2012:178), the study conducted by Wolter (2010:7) also could be a representation that student's character and SRL strategy were related to the vision of the 2013 Curriculum about 21 st 
century students. There are some common in students' character, SRL strategy and the demands of 21 st century students.

On the discussion presented, it could be concluded that if learning instruments had already been based on a student-centered approach, then experience/emotional attachment process would impact the students more effectively. As the result, it would help in increasing memory management which obviously did a great favor for students in creating more optimum learning experience output. Both from metacognitive skills and learning motivation. That was why, it was common that learning instruments based on scientific approach through SRL strategy had enough potential to increase students' metacognitive skills and learning motivation.

\section{CONCLUSION}

Based on the result and discussion that had been explained above, it could be concluded that: (1) the teaching kits developed through the SRL strategy in improving students' metacognitive skill and learning motivation were generally appropriate for biology learning; (2) there were differences in learning using the SRL strategy instruments with learning using the conventional instruments in improving SMA Negeri 1 Sentolo students' metacognitive skill and learning motivation. The differences also showed that the class using the SRL learning instrument had a better potential in improving the metacognitive skill and learning motivaton, compared to the class using the conventional learning instruments.

\section{ACKNOWLEDGEMENT}

The researcher thanked Direktorat Jenderal Pendidikan Tinggi (DIKTI) which facilitateed this research in the form of fund for the graduate team research in 2015 . Hopefully this research could give contribution, especially for education.

\section{REFERENCES}

Anandiou, K. \& Claro, M. 2009. 21st Century Skills and Competences for New Milleni- um Learners in OECD Countries. http://www.oecd-ilibrary.org/ed-ucation/21stcentury-skills-and-competences-for-newmillennium-learners-in-oecd-countries_218525261154. diunduh 1 Januari 2014.

Anderson, L.W. \& Krathwohl, D.R. 2001. A Taxonomy for Learning, Teaching, and Assessing: A Revision of Bloom's Taxonomy of Educational Objectives. New York: Wesley Longman.

Ardila, C., Corbima, A.D., dan Zubaidah, S. 2013. Hubungan Keterampilan Metacognitif terhadap Hasil Belajar Biologi dan Retensi Siswa Kelas X dengan Penerapan Strategi PermberdayanBerpikirMelalui Pertanyaan (PBMP) di SMAN 9 Malang. http://jurnal- online.um.ac.id/data/artikel/artikelEE88BC4B01504CB71615F1 D280FAF7AE.pdf. diunduh 11 Juli 2014.

Asmari, A.A. \& Ismail, N.M. 2012. "Self Regulated Learning Strategies as Predictors of Reading-Comperhensionamong Students of Englishas A Foregein Language". International Journal of Asian Social Science. 2(2):178-201.

Borg, W.R. \& Gall, M.D. 1983. Educational Research Fourth Edition. Pearson: United States of America.

Borich, G.D. 1994. Observation Skill for Effective Teaching $\left(2^{\text {nd }}\right)$. New York: McMilan Publishing Company.

Djukri \& Paidi. 2013. "Pengembangan Perangkat Pembelajaran Biologi Berbasis Pendekatan Saintifik di SMA di DIY". Usulan Peneltian Tim Pascasarjana, tidak Diterbitkan, Universitas Negeri Yogyakarta.

Grotzer, T \& Mittlefehldt, S. 2012. "The Role of Metacognition in Students' Understanding and Transfer of Explanatory Struc- 
tures in Science". Springer Journal, 40, 1878-0482.

Hidayat, Y. 2012. "Pengaruh Goal Setting dan Self Monitoring dalam Penguasaan Keterampilan Gerak dan motivasi Intrinsik Siswa Sekolah Dasar". Cakrawala Pendidikan, XXXI (3), 495-511.

Imel,S.2002. Metacognitive Skills for Adult Lea rning. http://files.eric.ed.gov/fulltext/ED4 69264.pdf. Diunduh 8 Juli 2013.

Mardapi, D. 2008. Teknik Penyusunan Instrumen Tes dan Nontes. Yogyakarta: Mitra Cendikia Press.

Paidi. 2008. "Pengembangan Perangkat Pembelajaran Biologi yang Mengimplementasikan PBL dan Strategi Metakognitif serta Keefektivitasnya terhadap Kemampuan Metakognitif, Pemecahan Masalah dan Penguasaan Konsep Biologi Siswa SMA di Sleman Yogyakarta”. Disertasi Doktor, Tidak Diterbitkan, Universitas Negeri Malang

Santyasa, I. W. 2013. "Pembelajaran Sains Inovatif: Strategi Self Regulated Learning sebagai Fasislitas Belajar Alternatif dalam Rangka Menjawab Tantangan Abad Ke-21". Makalah, Disajikan dalam Seminar Nasionaol Pendidikan Sains, di Universitas Negeri Yogyakarta

Schraw, G. \& Dennison, S. 1994. Assessing Metacognitive Awarenness. Contemp orary Educational Psychology, 19, 460475.

Suryanto. 2010. "Inovasi Pembelajaran PKn di SD untuk Memenuhi Tuntutan Sifat Kodrat Manusia Sebagai Mahluk Individu dan Sosial". Proceedings $2^{\text {nd }}$ International Seminar 2012 Practice Pedagogicin Global Education Prespective, Bandung, 2, 2086-2340.

Veenman, M.V.J. 2012. "Metacognition in Science Education: Definitions, Constituents, and Their Intricate Relation with Cognition”. Springer Journal, 40, 1 878-0482.

Whitebread, D., \& Cárdenas, V., G. 2012. "Self-Regulated Learning and Conceptual Development in Young Children The Development of Biological Understanding”. Springer Journal, 40, 1878-0482.

Wolters, C.A. 2010. Self Regulated Learning and The 21st Century Competencies. Departement of Educational Psycology University of Huston. http://www.hewlett.org/uploads/Self_Regulated_Learning__ 21st_Century_Competencies.pdf. Diunduh 23 Agustus 2014.

Zohar, A. 2012. "Explicit Teaching of Metastrategic Knowledge: Definitions, Students' Learning, and Tachers' Professional De-velopment". Springer Journal, 40, 1878-0482. 